\title{
Health information, an area for competition in Swedish pharmacies
}

Elin C. LARSSON, Nina VIBERG, Åsa VERNBY, Johanna NORDMARK, Cecilia STÅLSBY-LUNDBORG.

\begin{abstract}
Objective: To investigate the views and expectations of a selected group of customers regarding health information in Swedish pharmacies.

Methods: A repeated cross sectional, questionnaire study carried out in 2004 and 2005. Customers buying calcium products answered questions on osteoporosis and general questions on health promotion and information.

Results: Respondents had a positive attitude towards receiving health information from the pharmacies and towards the pharmacies' future role in health promotion. However, only $30 \%$ of the respondents expected to get information on general health issues from the pharmacy. In spite of this, $76 \%(2004)$ and $72 \%$ (2005) of the respondents believed that the pharmacies could influence people's willingness to improve their health. Conclusion: There is a gap between the respondents' positive attitudes towards the Swedish pharmacies and their low expectations as regards the pharmacies' ability to provide health information. In the light of the upcoming change to the state monopoly on medicine sales, this gap could be an important area for competition between the actors in the new situation for medicine sales in Sweden.
\end{abstract} Services. Health Promotion. Sweden.
Keywords: Pharmacies. Community Pharmacy

\author{
INFORMACIÓN SANITARIA, UN ÁREA DE \\ COMPETENCIA EN LAS FARMACIAS \\ SUECAS
}

\section{RESUMEN}

Objetivo: Investigar las visiones y expectativas de un grupo seleccionado de clientes en relación a la información en las farmacias suecas.

Métodos: Un cuestionario repetido transversal realizado en 2004 y 2005. Los clientes que compraban productos con calcio respondieron a preguntas sobre osteoporosis y preguntas generales sobre promoción de la salud e información.

Resultados: Los respondentes tenían una actitud positiva hacia recibir información de las farmacias y hacia el futuro papel del farmacéutico en la promoción de la salud. Sin embargo, solo el 30\% de los respondentes esperaba obtener información sobre aspectos generales de salud en la farmacia. A pesar de esto, el 76\% (2004) y 72\% (2005) de los respondentes creían que las farmacias podrían influir en la voluntad de las personas para mejorar su salud.

Conclusión: Hay una brecha entre las actitudes positivas de los respondentes hacia las farmnacias suecas y sus bajas expectativas sobre la capacidad de las farmacias de proporcionar información sobre la salud. A la vista del inminente cambio en el monopolio estatal de la venta de medicamentos, esta brecha podría ser un área importante de competencia entre los actores de esta nueva situación de venta de medicamentos en Suecia.

Palabras clave: Farmacias. Servicios de farmacias comunitarias. Promoción de la salud. Suecia.

\section{INTRODUCTION}

Elin C. LARSSON. MSc Pharm. Division of International Health (IHCAR), Department of Public Health Sciences, Karolinska Institutet. Stockholm (Sweden). Nina VIBERG. MSc Pharm. Division of International Health (IHCAR), Department of Public Health Sciences, Karolinska Institutet. Stockholm (Sweden). Åsa VERNBY. MSc. Division of International Health (IHCAR), Department of Public Health Sciences, Karolinska Institutet. Stockholm (Sweden). Johanna NORDMARK. MSc Pharm. Division of International Health (IHCAR), Department of Public Health Sciences, Karolinska Institutet. Stockholm (Sweden). Cecilia STÅLSBY-LUNDBORG. MSc Pharm, PhD. Nordic Schoool of Public Health (NHV) and Apoteket AB. Division of International Health (IHCAR), Department of Public Health Sciences, Karolinska Institutet. Stockholm (Sweden).
Health-seeking behavior changes continuously, and today much focus is on self-care. ${ }^{1}$ Health information has become more available through the Internet, the media, and increased advertising. ${ }^{1,2}$ However, the information available might be misunderstood and might lead to additional questions from the consumers, meaning that easy access to advice from trained personnel is essential. $^{2}$

A well accepted definition of health promotion is; "the science and art of helping people change their lifestyle toward a state of optimal health".,4 Promotion of a healthy lifestyle is one of the five core pharmacist roles defined by the Royal 
Pharmaceutical Society of Great Britain, and The International Pharmaceutical Federation (FIP) also states; "comprehensive pharmacy service involves activities both to secure good health and to avoid illhealth in the population". 5 The role of community pharmacists varies between countries but has in general shifted from earlier being more productfocused, to now being more patient-focused as has been described as "pharmaceutical care", defined by the FIP. ${ }^{2,3,6,7}$ The patient-focused approach, means that it is important that the pharmacy personnel have knowledge in areas such as; how to interact with individuals and populations through campaigns, how to be a good communicator with patients as well as with other health workers, and how to give high quality health advice. ${ }^{8,9}$ Community pharmacists have been argued to hold a unique position to reach out to people because of the physical location of pharmacies in the heart of communities, the long opening hours and the possibility to visit without an appointment. ${ }^{10,11}$

In Sweden, in contrast to most other countries, one government-owned company, Apoteket $A B$ has, since 1971, had the exclusive right to operate community pharmacies. ${ }^{12,13}$ The company has about 90 million customer visits each year and 800 community pharmacies. ${ }^{14}$ In areas where no pharmacies are available there are in total 1000 appointed pharmacy representatives such as grocery stores providing drugs. ${ }^{12-15}$ Apoteket $A B$ has 11,000 employees. Each pharmacy typically has a staff consisting of; 0-2 pharmacists (MSC Pharm), 7-10 prescriptionists (BSc Pharm) and 3-4 pharmacy technicians. ${ }^{15,16}$

Recently a governmental investigation was released which suggest that other actors than Apoteket $A B$ should get permission to sell medicines in Sweden. ${ }^{\uparrow}$

Apoteket $A B$ strives to focus more on public health issues and has since 1990 had yearly themes focusing on various health topics such as diabetes, infectious diseases, and in 2004 the topic was improved health through lifestyle changes. ${ }^{15}$ The aim of this study was to investigate a selected group of customers' views and expectations on health information in Swedish pharmacies.

\section{METHODS}

This was a repeated cross sectional study, with data collected from customers during two consecutive weeks each year, in the spring 2004 and in the fall 2005.

All community pharmacies, in total 61 , in two counties in Sweden (Värmland and Uppsala) were included in the study. These two counties were selected because they were part of a bigger study also including qualitative interviews with pharmacy personnel on their role as public health providers. The counties have about the same population size, are situated in the same region, but differ in socioeconomic structures, Värmland being more rural with a slightly older population of which fewer have a post-upper-secondary school education.
We wanted to target a group of pharmacy customers for which information both on prevention and treatment is essential. Osteoporosis is a disease of high prevalence $(>1 \%)$ in the Nordic countries and the prevalence of osteoporosis in Swedish women above 60 years of age is $37.9 \%$. Preventive actions as well as treatment is essential for this group. ${ }^{18,19}$ Calcium is used both for treating and preventing osteoporosis and calcium products can be bought both on prescription and over the counter (OTC). All customers buying calcium products, either OTC or with prescription were eligible for the study.

In the formative phase of the study, semi-structured interviews were held with seven pharmacy customers buying calcium products either OTC or with prescription. These interviews were then used as guidance when developing the questionnaire. The developed questionnaire was pre-tested on 11 customers in two pharmacies outside the study area. Thereafter some small changes and clarifications were made in the questionnaire. The final questionnaire included questions on personal characteristics, smoking, calcium intake, information received about osteoporosis, and more general questions about the pharmacies' role for health information and promotion. Altogether 23 questions were asked (questionnaire available in Swedish from first author).

Prior to the study, staff in the pharmacies were given instructions about how to administer the questionnaire and ask for informed consent from eligible customers. The customers were given written information stating that their participation was voluntary and anonymous. Pharmacy staff handed out and collected the questionnaires from eligible customers, the OTC customers were given the questionnaires at the checkout counter and the prescription customers were given the questionnaire from the pharmacy staff preparing their prescription. The questionnaire was filled in by the respondent in the pharmacy and thereafter given back to staff. In order to get an idea of how many of the customers buying calcium that participated in the study, the pharmacy staff was asked to make a note every time calcium products were sold and whether the customer agreed to fill in the questionnaire or not (Table 1).

\begin{tabular}{|l|c|c|}
\hline \multicolumn{3}{|l|}{ Table 1. Background information on respondents } \\
\hline \multirow{2}{*}{ Respondents } & 2004 & 2005 \\
\hline Female & $\mathrm{n}(\%)$ & $\mathrm{n}(\%)$ \\
\hline Mean age, yrs & $289(91)$ & 401 \\
\hline Smokers & 67 & $363(91)$ \\
\hline Type of respondents & $41(13)$ & 67 \\
\hline with prescription & $267(84)$ & $337(84)$ \\
\hline without prescription & $51(16)$ & $64(16)$ \\
\hline Estimated response rate ${ }^{a}$ & $318 / 511(62)$ & $401 / 693(58)$ \\
\hline Invited pharmacies & 61 & 61 \\
\hline Participating pharmacies & 51 & 49 \\
\hline $\begin{array}{l}\text { a of respondents/customers buying calcium according to staff } \\
\text { notes }\end{array}$ \\
\hline
\end{tabular}

Data was analyzed using SPSS for Windows 10.0. Descriptive statistics were calculated for the relevant questionnaire items and years. The intra- 
class correlation coefficient (ICC) was calculated for the clustering of patients' answers with regard to which pharmacy they visited from estimates obtained from procedure Mixed in SAS 9.1.3 (SAS Institute Inc., Cary, NC, USA), in which a one-way random effects model was fitted.

\section{RESULTS}

The estimated response rate, based on staff notes, as described earlier, was $62 \%$ in 2004 and $58 \%$ in 2005. The number of respondents was 318 in 2004 and 401 in 2005. For background information of the respondents (Table 1 ).

When comparing the results between the two years there were no statistically significant differences between the respondents' answers to the key questions (Table 2).

The intra-class correlation coefficient (ICC), a measure of how well the respondents' answers correlated with the pharmacy they visited, was calculated for the key questions. The ICC was very low for all questions, and not significantly different from zero for any of the questions. This means that the answers from the respondents did not depend on which pharmacy they had visited, and further analyses were done under the assumptions that the respondents' answers are independent.

About half of the respondents in both years reported that they wanted to know more about how to prevent osteoporosis, and a high percentage of the respondents considered the pharmacy as a place to obtain this information from (Table 2).

\begin{tabular}{|c|c|c|c|c|}
\hline & \multicolumn{2}{|r|}{2004} & \multicolumn{2}{|c|}{2005} \\
\hline & $\mathrm{n}$ & $\%(95 \% \mathrm{Cl})$ & $\mathrm{n}$ & $\%(95 \% \mathrm{Cl})$ \\
\hline \multicolumn{5}{|c|}{ Would you like to know more about how to prevent osteoporosis? } \\
\hline Yes & 177 & $55(50: 61)$ & 210 & $52(47: 57)$ \\
\hline No & 86 & $27(22: 32)$ & 131 & $33(28: 37)$ \\
\hline Do not know & 36 & $11(8: 15)$ & 32 & $8(5: 11)$ \\
\hline Not answer & 20 & $6(4: 9)$ & 28 & $7(4: 9)$ \\
\hline \multicolumn{5}{|c|}{ Is the pharmacy a place you consider you can obtain information about osteoporosis? } \\
\hline Yes & 169 & $53(48: 58)$ & 196 & $49(44: 54)$ \\
\hline No & 11 & $3(1: 5)$ & 7 & $2(0: 3)$ \\
\hline Do not know & 34 & $11(7: 14)$ & 35 & $9(6: 11)$ \\
\hline Not answered & 105 & $33(28: 38)$ & 163 & $41(36: 45)$ \\
\hline \multicolumn{5}{|c|}{ Which of the following topics do you expect to get information about from the pharmacy? } \\
\hline Drugs & 261 & $82(78: 86)$ & 316 & $79(75: 83)$ \\
\hline General health issues & 106 & $33(28: 39)$ & 156 & $39(34: 44)$ \\
\hline Diet & 78 & $25(20: 29)$ & 92 & $23(19: 27)$ \\
\hline Tobacco cessation & 66 & $21(19: 25)$ & 83 & $21(17: 25)$ \\
\hline Diseases/illnesses & 58 & $18(14: 22)$ & 93 & $23(19: 27)$ \\
\hline Exercise & 47 & $15(11: 19)$ & 79 & $20(16: 24)$ \\
\hline \multicolumn{5}{|c|}{ Do you believe that the pharmacy could influence the people's willingness to improve their health? } \\
\hline Yes & 243 & $76(72: 82)$ & 290 & $72(68: 77)$ \\
\hline No & 10 & $3(1: 5)$ & 11 & $3(1: 4)$ \\
\hline Do not know & 55 & $17(13: 21)$ & 72 & $18(14: 22)$ \\
\hline Not answered & 10 & $3(1: 5)$ & 28 & $7(4: 9)$ \\
\hline \multicolumn{5}{|c|}{ How important do you think the pharmacy will be in the future for health promotion? } \\
\hline Of little importance or not important at all & 9 & $3(1: 5)$ & 8 & $2(1: 3)$ \\
\hline Medium & 89 & $28(23: 33)$ & 87 & $22(18: 26)$ \\
\hline Important or very important & 148 & $47(41: 52)$ & 179 & $45(40: 50)$ \\
\hline Do not know & 61 & $19(15: 24)$ & 96 & $24(20: 28)$ \\
\hline Not answered & 11 & $3(1: 5)$ & 31 & $8(5: 10)$ \\
\hline
\end{tabular}

On given topics, the respondents were asked to tick which of the topics they expected to get information about from the pharmacy and several of the topics could be ticked by each respondent. In both years, rather low percentage of the respondents expected to receive health information such as general health issues, diet, and smoking cessation. About three out of four of the respondents' believed that the pharmacies could influence people's willingness to improve their own health (Table 2). When asked to grade the pharmacies' role for health promotion in the future, the most common answers were important or very important, and notably few graded the role as of little importance (Table 2).

\section{DISCUSSION}

The majority of the respondents believed that pharmacies can play a major role for health promotion in the future and that pharmacies can influence people's willingness to improve their health. Thus our findings strongly support the vision of pharmacies as places appropriate for health promotion as stated by FIP and the defined role of the pharmacist. ${ }^{3,5}$ However our findings also show that a selected group of pharmacy customers have rather low expectations when it comes to receiving information on general health and life style changes. Other international studies have shown that customers consider pharmacies as places where to receive social support for health improvements, as well as places suitable for health promotion. ${ }^{11,20}$ The point has also been raised that pharmacies, unlike, 
for example, primary health care centers, are more accessible because of the location, the opening hours and the fact that people do not need an appointment to go there. ${ }^{11,20,21}$

The state monopoly in Sweden is currently under review which might lead to other actors entering the market. $^{22}$ Our results show no significant clustering of customers' answers depending on which pharmacy they had visited. This indicates that information given by the pharmacy staff, as perceived by customers, was similar in all pharmacies.

The consistency in the respondents' answers as well as the respondents' positive attitudes towards the pharmacies is a situation that could be used by the government-owned company as a competitive advantage in the era of competition in the near future, especially since the government-owned company already has the infrastructure is in place to reach a large number of people in the whole country.

Our results are based on respondents from Sweden where all community pharmacies are state-owned and the study targeted a selected group of customers in two purposively selected counties. This together with the fact that the pharmacy staff handed out the questionnaires could have introduced potential selection biases. One example is that sales statistics show that there were roughly 3.2 prescription customers per OTC customer in 2004, in 2005 the corresponding figure was 3.6, these are estimates based on the number of calcium product packages sold. ${ }^{23}$ Among our respondents the corresponding figures were 5.2 in 2004 and 5.3 in 2005, meaning that there was a slight overrepresentation of prescription customers in our study. However the responses from OTC customers were not different from the responses from prescription customers.
The estimated response rate was about $60 \%$ in both years. These figures are based on staff notes and might not be the true response rate, since staff might forget to write down when people bought calcium products or when people accepted or declined to participate in the study. The proportion of women among respondents was approximately $90 \%$ for both years of the study, which is in accordance with the proportion of women diagnosed with osteoporosis. ${ }^{24}$ Although not generalizable to all pharmacy customers, we believe that the results are valuable as a description of the views of the selected group, and that the results can contribute to the understanding of the pharmacy as a place for health promotion.

\section{CONCLUSIONS}

There is a gap between the respondents' positive attitudes towards the Swedish pharmacies and their low expectations as regards the pharmacies' ability to provide health information. In the light of the upcoming change to the state monopoly on medicine sales, this gap could be an area important for competition between the actors in the new situation of medicine sales in Sweden.

\section{ACKNOWLEDGEMENTS}

This study was supported by a grant from Apoteket $A B$. We are most grateful to all customers and staff members at the pharmacies who gave their time to participate in the study. We are also grateful to Frida Lundmark for her contributions.

\section{CONFLICT OF INTEREST}

None declared.

\section{References}

1. Anderson C. Health promotion in community pharmacy: the UK situation. Patient Educ Couns. 2000;39(2-3):285-291.

2. The International Pharmaceutical Federation. FIP Statement of professional Standards, Pharmaceutical Care. Council meeting in the Hague 1998 [cited; 06-07-02] URL:

http://www.fip.org/www2/uploads/database_file.php?id=269\&table_id=.

3. Royal Pharmaceutical Society of Great Britain (RPSGB), Pharmacy in a new age, summary of responses. 1996: London.

4. O'Donnell M. Definitions of health promotion. Am J Health Promotion 1986;1:4.

5. The International Pharmaceutical Federation. Standards for quality of pharmacy services. 1997 [cited; 060615] Available from: http://www.fip.org/www2/uploads/database_file.php?id=261\&table_id=.

6. Anderson S. The state of the world's pharmacy: a portrait of the pharmacy profession. J Interprof Care. 2002;16(4):391404.

7. Muijrers PE, Knottnerus JA, Sijbrandij J, Janknegt R, Grol RP. Pharmacists in primary care. Determinants of the careproviding function of Dutch community pharmacists in primary care. Pharm World Sci. 2004;26(5):256-262.

8. Cordina M, McElnay JC, Hughes CM. Societal perceptions of community pharmaceutical services in Malta. J Clin Pharm Ther. 1998;23(2):115-126.

9. Chandra A, Malcolm N 2nd, Fetters M. Practicing health promotion through pharmacy counseling activities. Health Promot Pract. 2003;4(1):64-71.

10. Hassell K, Noyce P, Rogers A. A review of factors that influence the use of community pharmacies as a primary health care resource. Int J Pharm Pract. 1999;7:51-59.

11. Hassell K, Rogers A, Noyce P. Community pharmacy as a primary health and self-care resource: a framework for understanding pharmacy utilization. Health Soc Care Community. 2000;8(1):40-49.

12. Westerlund LT, Bjork HT. Pharmaceutical care in community pharmacies: practice and research in Sweden. Ann Pharmacother. 2006;40(6):1162-1169. 
13. Neroth $P$. Sweden's state pharmacies may lose hold over drug sales. Lancet, 2005. 365(9477): p. $2079-80$.

14. Apoteket AB. Apoteket på två minuter. 2006 [cited 060714]; Available from: (http://www2.apoteket.se/Apoteket/om/VilkaViAr/default.htm060714), .

15. Apoteket AB, Annual Report 2005. 2006: Stockholm.

16. Westerlund T. A National Pharmacy Chain - Pros and Cons of the Swedish System. J Manag Pharm Care. 2001;1:8388.

17. Apoteksmarknadsutredningen, Omreglering av apoteksmarknaden, SOU 2008:4, Socialdepartementet, Editor. 2008.

18. European Commission. Report on osteoporosis in the European Community. Action for prevention. 1998.

19. Ekman A. Hips at Risk Osteoporosis and Prevention of Hip Fractures in Department of Surgical Sciences, Section of Orthopaedics. 2001, Uppsala University: Uppsala. p. 84.

20. Cavaco AM, Dias JP, Bates IP. Consumers' perceptions of community pharmacy in Portugal: a qualitative exploratory study. Pharm World Sci. 2005;27(1):54-60.

21. Hudmon KS, Prokhorov AV, Corelli RL. Tobacco cessation counseling: pharmacists' opinions and practices. Patient Educ Couns. 2006;61(1):152-60.

22. Department S. Kommittédirektiv. Omreglering av apoteksmarknaden, Social, Editor. 2006, Social Department.

23. Apoteket AB. Sale statistics from 2004 and 2005, M. Wirén, Editor. 2007, Apoteket AB: Stockholm.

24. Statens beredning för medicinsk utvärdering (SBU), Osteoporos-prevention, diagnostik och behandling. En systematisk litteraturöversikt. 2003: Göteborg. 